\title{
PEDAGOŠKI ODNOS KAO POTENCIJAL PROMJENE U BALETNOM ŠKOLOVANJU
}

\author{
MIHAELA DEVALD ROKSANDIĆ \\ Nezavisna istraživačica, Zagreb
}

\begin{abstract}
U ovom radu baletno se školovanje promatra iz pedagogijske perspektive, odnosno biva sagledano kao odgojno-obrazovni proces čiju centralnu dimenziju čini pedagoški odnos između nastavnika i učenika. Analiziraju se opresivne pedagoške prakse, stavovi i vrijednosti koji se, unutar baletne obrazovne vertikale, tradicijski prenose "s koljena na koljeno" bez kritičkog propitivanja. Poseban je fokus na pravima djeteta i njihovu poštivanju u procesu odgoja i obrazovanja, uz analizu diskriminatornih obrazaca selekcije djece koji i danas egzistiraju u baletnim školama diljem svijeta. Tako se fokus pomiče s onog što je "važno za profesiju" na nužnost uvažavanja najboljeg interesa djeteta u procesu baletnog školovanja. U obradi teme primijenjena je autoetnografska metoda istraživanja, pri čemu su kao kvalitativni podaci korištena i različita osobna iskustva stečena kroz školovanje i plesačku te pedagošku karijeru. Temeljem tih iskustava i teorijskog istraživanja ovaj rad pokušava ponuditi rješenja za promjenu u procesu baletnog školovanja te ih pronalazi upravo u potencijalnom pedagogijskom doprinosu baletnoj pedagogiji. Mogućnost promjene kvalitete odnosa između nastavnika i učenika prezentirana je kroz pedagoški odnos s obzirom na to da osvještavanje i artikulacija svih segmenata pedagoškog odnosa donose potencijal promjene koji je nužan u procesu baletnog školovanja. Zahtjevom za pedagogičnim artikuliranjem pedagoškog odnosa, kao temeljnog pedagoškog koncepta u baletnom školovanju, i dalje se uvažavaju zahtjevi koje pred dijete postavlja baletna umjetnost, ali se istovremeno afirmiraju prava i najbolji interes djeteta.
\end{abstract}

Ključne riječi: baletno školovanje, idealno baletno tijelo, diskriminacija, autoritarne pedagoške prakse, pedagoški odnos

\section{UVOD - BALET JE PRONAŠAO MENE...}

Plešem, gotovo otkada znam za sebe. Na pitanje - kako je sve počelo, teško mogu dati konkretan odgovor. Ples je naprosto oduvijek bio jezik koji sam intuitivno razumjela i kojim sam se kreativno izražavala. Želja za plesanjem dovela me, u dobi od pet godina, do vrata baletne škole na llirskom trgu, a talent i upornost su me, desetak godina kasnije odveli do 
baletne dvorane HNK-a u Zagrebu u kojem sam provela više od trideset godina profesionalne baletne karijere. Balet je za mene oduvijek bio puno više od posla kojim zarađujem za život, on je bio poziv koji je odredio sve ono što danas jesam. Balet me oblikovao kao osobu (u gotovo jednakoj mjeri kao što su to odgojem učinili moji roditelji) te upravo baletu mogu zahvaliti neke od osobina koje su bile ključne za mnoga postignuća kojima se ponosim. Isto tako, balet je imao presudan utjecaj na moj izgled, način odijevanja, ali i ophođenja s ljudima kroz obrasce ponašanja te dominantnu estetiku koju sam usvajala tijekom svog školovanja. Veći dio života osjećala sam se istinski privilegiranom stoga što sam uspjela u svijetu u kojem ostaju i opstaju rijetki, objašnjavajući to rečenicom "ja sam voljela balet, a i balet je volio mene".

Ipak, iako sam u baletu proživjela neke od najljepših trenutaka te ostvarila postignuća na koja ću uvijek biti iznimno ponosna, s vremenom sam postajala sve svjesnija kako ta umjetnost pod svojim magičnim plaštem krije mnoge degradirajuće, opresivne i diskriminatorne te suštinski pogrešne prakse. Čak i moja omiljena rečenica u kojoj je "balet volio mene" vrlo jasno govori o tome kako postoje mnogi oni koje balet nije volio te in je, ne mogavši ih podčiniti ili apsorbirati, odbacio. Taj nedostatak inkluzivnosti te osjećaja za "druge i drugačije"1 u najvećoj mjeri očituje se upravo u pedagoškim praksama koje se u baletnoj umjetnosti često nekritički primjenjuju. Spomenute se prakse (o kojima ću opširnije govoriti u nastavku rada) unutar same baletne zajednice percipiraju kao "normalne" te se njihovo preispitivanje i mijenjanje uglavnom ne potiče. Također, upravo su spomenute problematične prakse ono što temeljno određuje baletnu umjetnost. Ova zapažanja prvenstveno se odnose na metode i sustav baletnog školovanja koji, svojim dogmatičnim pristupom, imaju snažan utjecaj na razvoj osobnosti mladih plesača te ostavljaju posljedice koje se odražavaju i u profesionalnom (ali i privatnom) životu. Ključni trenutak mog osobnog osvještavanja dogodio se 2004. godine, kada je, nakon dvije godine sustavnog maltretiranja, na vidjelo izašao slučaj mobbinga plesačica baletnog ansambla te snažno odjeknuo u hrvatskoj javnosti. ${ }^{2}$ Svjedočeći osobno mnogim situacijama koje su kasnije bile javno prezentirane te su dobile i svoj sudski epilog, nisam se mogla prestati pitati kako je moguće da zajednica od osamdesetak odraslih ljudi ne samo trpi nego i uvelike opravdava nasilje koje se svakodnevno događalo pred njihovim očima. Odgovore na ta, ali i mnoga druga pitanja dobila sam u nastavku procesa vlastitog obrazovanja kojem sam pristupila u zrelim godinama. ${ }^{3}$ Ono mi je pomoglo osvijestiti mnoge maligne postupke kojima sam

\footnotetext{
${ }^{1}$ U nastavku rada opširnije ću se baviti estetikom klasičnog baleta koja, svojom isključivošću, diskriminira pojedina tijela temeljem njihova izgleda, građe i određenih fizičkih značajki. Na taj način estetski "nepoželjna tijela" možemo percipirati kao "druga i drugačija”. lako je baletna estetika jedno od temeljnih obilježja baletne umjetnosti, te neizostavan faktor u profesionalnom bavljenju baletom, važno je osvijestiti kako inzistiranje na estetskim kriterijima tijekom baletnog školovanja može imati diskriminatorni karakter.

${ }^{2}$ Ovdje mislim na slučaj mobbinga iz 2004. godine koji se dogodio u Baletu HNK-a u Zagrebu te je rezultirao javnim skandalom, ali i sudskim procesom između ravnatelja i zaposlenice koji je završen u njezinu korist.

${ }^{3}$ Godine 2013. upisujem novootvoreni preddiplomski studij baletne pedagogije pri Akademiji dramske umjetnosti te tako, u četrdeset trećoj godini života, postajem jedna od studentica prve upisane generacije. Studij završavam 2016. godine, nakon čega upisujem diplomski studij pedagogije na Filozofskom fakultetu u Zagrebu na kojem sam i diplomirala 2019. godine.
} 
često i sama bila izložena. U tom smislu, proces obrazovanja za mene je postao i proces osobnog iscjeljenja te me potaknuo na promjenu i djelovanje unutar plesne zajednice, korištenjem znanja koje sam stekla na fakultetu.

Odmah na početku važno je naglasiti kako je ovaj rad napisan iz pedagogijske perspektive koja će se eksplicitno očitovati kroz isticanje nužnosti uvažavanja najboljeg interesa djeteta $u$ procesu baletnog školovanja. ${ }^{4} U$ tom smislu mogu reći da je moja namjera bila preispitati sve one pedagoške prakse koje su vrlo suptilno uvezane u baletnu svakodnevicu, a koje se iz pedagogijske perspektive mogu okarakterizirati kao opresivne i diskriminatorne te ponuditi prostor djelovanja i mogućnosti pedagogijskog doprinosa unutar tog petrificiranog sustava.

Upravo zato smatram kako je važno da rad koji propituje baletnu umjetnost bude napisan iz insajderske pozicije koja pretpostavlja vrlo dobro poznavanje i razumijevanje svih ustaljenih praksi te implicitnih i eksplicitnih pravila koja su dio baletnog školovanja, ali i, što je još važnije, njegova skrivenog kurikuluma, tj. onoga što ostaje neizrečeno, a što to isto školovanje temeljno određuje. Insajderska pozicija, u ovom slučaju, omogućuje mi prijeko potreban legitimitet te otvara mogućnost razgovora i argumentirane debate $s$ baletnom zajednicom stoga što se, budući da i sama pripadam toj zajednici, moje tvrdnje (iako ne moraju biti prihvaćene) teško mogu odbaciti kao neznalačke i nestručne. Ključnim smatram kritički pristup koji mi je pomogao da sve sporne prakse koje sam i sama donedavno vidjela kao samorazumljive i "normalne" ispitam na podlozi teorijskih spoznaja s kojima korespondiraju. $U$ tom smislu, pri pisanju ovog teksta morala sam primijeniti metodu narušavanja automatizma percepcije koju Valentina Gulin Zrnić objašnjava kao "temeljito propitivanje načina na koji obično razmišljamo" (Gulin Zrnić 2006: 87). Za mene osobno, "narušavanje automatizma percepcije" dogodilo se u procesu obrazovanja kada sam shvatila da "svoju" umjetnost snažnije zastupam onda kada je kritički promatram nego kada je bespogovorno branim. Pri pisanju ovog rada u jednakoj sam mjeri koristila svoje plesačko kao i pedagoško iskustvo jer smatram da mi upravo ta pozicija koja se nalazi "s obje strane ogledala" te objedinjuje plesnu praksu i pedagoški rad omogućuje donošenje zaključaka i predlaganje određenih rješenja koja su podjednako utemeljena u plesno pedagoškoj teoriji te provjerena u plesnoj praksi.

\section{PROBLEM: BALETNO ŠKOLOVANJE - SLIJEPA PJEGA OBRAZOVNOG SUSTAVA}

Baletno školovanje koje započinje kao strukturirano provođenje slobodnog vremena djeteta da bi u srednjoj školi uz određene uvjete preraslo u strukovno umjetničko obrazovanje

${ }^{4}$ Ovaj je članak nastao selekcijom i sintetiziranjem određenih dijelova diplomskog rada "Pedagoški odnos kao potencijal promjene u baletnom školovanju”. 
(Škola za klasični balet) ${ }^{5}$ na neki način predstavlja "slijepu pjegu" obrazovnog sustava. Dakle, iako je ono, u formi umjetničkog obrazovanja, sastavni dio obrazovnog sustava, ipak ne podliježe kvalitativnim provjerama nastavnog procesa, vobičajenim u općem osnovnoškolskom i srednjoškolskom obrazovanju. Ta zanemarenost područja umjetničkog obrazovanja te potpuni nedostatak pedagoške evaluacije njegova nastavnog procesa (ovdje prvenstveno mislim na područje baletne umjetnosti) omogućava provođenje, održavanje i regeneriranje mnogih problematičnih pedagoških praksi koje se u samoj baletnoj profesiji tumače kao "normalne" i nužne te ustvari postaju njezino osnovno obilježje. To se prvenstveno odnosi na sustav vrijednosti koji je duboko utisnut u sve razine bavljenja baletnom umjetnošću (od školovanja do profesionalne razine), a koji se unutar same zajednice ni na koji način ne dovodi u pitanje. Tako usvojen i internaliziran sustav vrijednosti koji sama zajednica bespogovorno prihvaća te ga proglašava normalnim "često tvori svojevrstan štit i opravdanje vobičajenih praksi” te iste zajednice (Katarinčić 2013a: 80) i dodatno je zatvara i izolira od izvanjskog svijeta. Također, rečeni sustav vrijednosti počinje se usvajati već na prvom koraku, u procesu baletnog školovanja pa je više nego nužno promotriti kako "tradicionalna, autokratska i autoritarna plesna pedagogija perpetuira forme rasnog, kulturalnog i rodnog elitizma i ekskluziviteta” (Bolt 2008: 1).

Sa spomenutom samorazumljivošću susrela sam se i sama, u procesu vlastitog obrazovanja. Tako sam na mnoga pitanja koja su u tom procesu neminovno iskrsnula odgovarala poznatom obrambenom rečenicom - "to je u baletu tako/vobičajeno/normalno!" Ta rečenica, toliko česta među baletnim profesionalcima, stavlja točku i prije nego što je pitanje do kraja postavljeno. Baletni stavovi i baletne vrijednosti su konačni, oni se ne propituju, a odgovor je uvijek isti. Balet egzistira u okvirima svojih dogmi; discipline, autoritarnosti, poslušnosti i tijela koje zadovoljava točno određene estetske parametre. Svaki iskorak iz tog hermetički zatvorenog kruga "više nije balet”. Takvu "ideološku zloupotrebu koja se skriva u običaju da se dekorativno iznose stvari koje se razumiju same po sebi" te se opisuju kao "normalne" i "prirodne", francuski filozof i lingvist Roland Barthes naziva - mit (Barthes 2009: 10). Prema Barthesu, mit nastaje kada se miješaju povijest i priroda: "bila davna ili ne, mitologija može imati jedino povijestan temelj, jer je mit iskaz koji je izabrala povijest: on ne može niknuti iz prirode stvari” (ibid.: 143). U kontekstu baletne umjetnosti zanimljivo je Barthesovo viđenje figura kroz koje se mit prikazuje. Tako, kao jednu od figura Barthes ističe tautologiju ${ }^{6}$ te objašnjava kako "u tautologiji tražite utočište kao u strahu, ili srdžbi, ili u tuzi kad ne znate čime biste stvari objasnili. [...] Tako roditelji stjerani u škripac odgovaraju djetetu koje ih zapitkuje tražeći objašnjenja: to je tako, zato što je to tako" (ibid.: 176) dok baletna zajednica gorljivo brani svoje vrijednosti rečenicom "to je u baletu tako, zato što je to balet". Budući da se baviti baletom započinje u najranijoj dobi te da baletna umjetnost, zbog zahtjevnosti same tehnike, u svojim temeljima sadrži disciplinu i poslušnost koje,

\footnotetext{
${ }^{5}$ Ova definicija baletnog školovanja odnosi se prvenstveno na model koji postoji u Republici Hrvatskoj u kojem se, nakon završene osnovne baletne škole, polaže audicija za prijem djeteta u srednju baletnu školu, čime baletno školovanje postaje "strukovno umjetničko obrazovno usmjerenje" (Škola za klasični balet).

${ }^{6}$ Tautologija je verbalni postupak uz pomoć kojeg isto definiramo istim - "Kazalište je kazalište" (Barthes 2009: 176).
} 
ako nisu kritički evaluirane, mogu postati "opasno oružje” u podčinjavanju poslušnih tijela, izuzetno je važno razlučiti mit od stvarnosti. U tom smislu, u nastavku ovog rada pokušat ću odgovoriti na pitanja "zašto je to u baletu tako?", "može li se to u baletu promijeniti?" te "hoće li, u slučaju promjene to i dalje ostati balet?".

\section{PEDAGOŠKE KOMPETENCIJE NASTAVNIKA BALETA}

Spomenuti petrificirani stavovi, koji spadaju u svojevrsno tradicijsko nasljeđe baletne umjetnosti, prenose se tzv. insajderskim diskursima te možemo reći kako se regeneriraju i opstaju unutar baletne obrazovne vertikale uglavnom temeljem stava prema kojem se profesionalne kompetencije za podučavanje klasičnog baleta stječu prvenstveno plesačkom praksom, odnosno "iskustvom plesanja", a ne teorijskim obrazovanjem. Tako se, regrutirajući učiteljski i nastavnički kadar većim dijelom iznutra (iz plesačke struke) ne potiče kritički pogled "sa strane" koji bi omogućio znanstvenu evaluaciju spornih praksi. Takav način razmišljanja, prema kojem se pozitivno vrednuje prvenstveno plesačka karijera, dovodi do toga da se, procesom školovanja, uz znanje i vještine izvođenja koraka, nekritički prenosi i ono što se u literaturi naziva baletna ideologija. Budući da i sama pripadam prvoj generaciji studenata upisanoj na preddiplomski studij baletne pedagogije, koji je 2013. godine otvoren pri Akademiji dramske umjetnosti, a istovremeno sam balerina s ostvarenom profesionalnom karijerom, mogu i osobno posvjedočiti koliko puta sam se, u svom profesionalnom okruženju, suočila s pitanjima koja su se sa sumnjom odnosila spram sadržaja s kojima se susrećem na fakultetu. Pitanja poput "što te oni mogu naučiti, a da ti već ne znaš?" pokazuju nerazumijevanje spram mogućnosti koje nudi akademsko plesno obrazovanje, ali i neosviještenost spram svih pogrešaka te nerealiziranih potencijala koji su prisutni u današnjem baletnom školovanju. Iz svega navedenog moguće je zaključiti kako kompetencije za podučavanje baleta nisu nešto što se dokazuje obrazovanjem, već se dodjeljuje temeljem postojanja plesačke karijere, kao i procjene njezine uspješnosti. Smatram da su takva praksa i razmišljanje neosnovani te da uspješnost nečije plesačke karijere govori jedino o sposobnosti izvođenja i interpretacije plesnih koraka, a ne o nečijoj sposobnosti prenošenja koraka u formi znanja i vještina. Nadalje, vještina izvođenja, kojom osoba ovladava tijekom plesačke karijere, može, ali i ne mora biti tzv. dodana vrijednost nečijim pedagoškim kompetencijama. Naime, postoji velik broj plesača koji plešu gotovo intuitivno, slijedeći svoj unutarnji osjećaj te u konačnici imaju poteškoća s verbalnom artikulacijom izvedenog. Georg Hans Neuweg u svojoj knjizi Šutnja znalaca to naziva problemom instrukcije navodeći kako "prikazivost umijeća u formi znanja ima svoje granice" (Neuweg 2008: 24). Prema Neuwegu, to se odnosi na one situacije u kojima određeno umijeće nije moguće prikazati kroz set jasnih pravila.? Međutim, koliko god plesna umjetnost bila subjektivizirana $u$ trenutku izvedbe te utjelovljena kroz samog

7 Primjeri koje Neuweg navodi u knjizi: “[Nijedan čovjek ne može nabrojiti pravila prema kojima postupaju ljudi kojima neprestano na um padaju novi i dobri vicevi. I nitko ne može reći što zapravo u određenoj 
izvođača, ona se ipak (a pogotovo kada govorimo o klasičnom baletu) bazira na vrlo jasnim pravilima izvođenja koraka. Tako možemo reći da vještina izvođenja koraka može postati komplementarna i pozitivno upotpunjujuća s umijećem prenošenja te iste vještine jedino kroz proces obrazovanja nastavničkog kadra.

lako se, razmatrajući "strukture i granice iskustvenog znanja", Neuweg u svojoj knjizi prvenstveno referira na umijeće podučavanja i znanje o podučavanju, neka su njegova promišljanja u potpunosti relevantna za ovu temu. Tako Neuweg znanje i umijeće razlikuje kao stručnost verbalizacije i stručnost djelovanja, artikulirajući dodatno te dvije vrste znanja kroz eksplicitno i implicitno znanje. Ipak, Neuweg tvrdi da zadatak učitelja nije "neprestano grozničavo povezivati teoriju i praksu”, nego je važno razvijati kulturu "upuštanja u djelovanje" koja ne smije dopustiti znanju (teoriji) da blokira praksu, postavljajući se u hijerarhijski nadređeni položaj. Također, razmatrajući izgradnju znanja, Neuweg navodi kako se znanje izgrađuje "kulturom distance" koja mu omogućuje odmak od imperativa praktične primjene (Neuweg 2008: 37). Kultura distance omogućuje nam prije svega inovaciju pedagoškog djelovanja stoga što se odmiče (distancira) od "trenutačno vobičajenih obrazaca školske prakse" (ibid.). Također, prema Neuwegu, "iskustvo postaje didaktički korisno tek ondje gdje se susreće sa spremnošću i sposobnošću za mišljenje stoga što naučiti kroz iskustvo može samo onaj tko kroz iskustvo nešto iskusi" (ibid.: 39). U zaključku Neuweg navodi kako "nastavnik ne postaje profesionalac na temelju svojega eksplicitnog niti implicitnog znanja već onda kada je spreman sam redovito analizirati, evaluirati i eventualno mijenjati svoju praksu te ako želi i može preuzeti odgovornost za vlastiti rast" (ibid.: 40). Upravo izgradnja "refleksivnog habitusa" i "refleksivnih kompetencija" čine mi se posebno važnim u kontekstu baletne umjetnosti. Naime, prema Neuwegu, gledišta i sposobnosti stečeni u praksi mogu se u praksi jednako tako i izgubiti (ibid.). Dakle, ako implicitno znanje stečeno u praksi ne preispitujemo na podlozi teorijskih spoznaja te ga tako transformiramo i mijenjamo, neprestano ga obogaćujući, ostajemo "zarobljenici" vlastitih iskustava koja, u konačnici, i ne moraju biti široko primjenjiva. To je pogotovo važno stoga što baletno školovanje u sebi dominantno sadrži elemente treninga i discipline koji, ako nisu utemeljeni na teorijskim osnovama te kritički evaluirani, mogu u mnogim segmentima naštetiti razvoju mlade osobe.

\section{POSTOJI LI DEMOKRACIJA U IZBORU BALETNIH TIJELA?}

Plesačko tijelo, koje je primarni objekt baletne obuke/treninga, možemo promatrati i kroz Bourdieuov koncept fizičkog kapitala ${ }^{8}$ te je u tom smislu važno promotriti kako društvene

društvenoj situaciji čini netko tko posjeduje socijalne kompetencije. Umijeće iza duhovitosti ili iza socijalne kompetencije su primjeri znanja koje se ne da formalizirati (Neuweg 2008: 24).

${ }^{8}$ Kao glavne forme kapitala Bourdieu navodi socijalni kapital koji se definira kao "mreža utjecajnih ljudi koju možemo iskoristiti kao potporu", zatim simbolički kapital koji znači da je osoba prepoznata i poštovana te da ima čast i ugled u društvu te kulturni kapital koji je povezan s obrazovanjem. Tijelo se prema toj podjeli može vidjeti kao forma fizičkog kapitala koji je dijelom povezan sa socijalnim kapitalom, stoga što je uprav- 
prakse klasičnog baleta utječu na formiranje fizičkog kapitala baletnog tijela te koje su im posljedice. Prema Wainwrightu i suradnicima, razlike u fizičkom kapitalu baletnih plesača mogu direktno odrediti plesačevu sudbinu te putanju kojom će se razvijati nečija karijera (Wainwright, Williams i Turner 2006: 548). Moguće je, dakle, tvrditi kako upravo fizički kapital (fizički predisponirano tijelo) postaje ulaznica u "čarobni svijet baletne umjetnosti". Pritom se ne procjenjuje i ocjenjuje samo baletno tijelo već i mogućnost sudjelovanja tog tijela u procesu baletnog školovanja. Izuzetno diskutabilan odnos prema tijelu kao i procjenjivanje nečije vrijednosti isključivo prema fizičkim karakteristikama dio je stavova i vrijednosti koji se ne izriču direktno (iako je i to ponekad moguće), nego su implicitno izražene te se očituju u skrivenom kurikulumu škole. ${ }^{9}$ Prema Risneru, implicitne poruke jasno se oslikavaju u načinu provođenja pedagoških praksi: "Mora biti jasno kako način na koji vodimo probu, koreografiramo, podučavamo ili pišemo, odražava način na koji doživljavamo svijet i uobličavamo cjelokupnost u kojoj živimo (Risner 2000: 155).

Moja baletna priča započela je u zagrebačkoj baletnoj školi na llirskom trgu gdje sam, u dobi od pet godina, počela pohađati pripremni tečaj baleta koji je služio razvijanju plesnosti, muzikalnosti i koordinacije. Od zaista velikog broja djece koja su bila na tečaju samo je jedan dio njih, nakon audicije, primljen u prvi razred baletne škole. Naime, baletnu školu ne mogu upisati sva djeca koja to žele. Prije samog upisa dijete mora proći audiciju na kojoj će se utvrditi posjeduje li ono sve potrebne predispozicije za pohađanje baletne škole.

$\cup$ baletu nema demokracije $u$ izboru potencijalnih plesnih tijela. Kodificiranost tehnike i izgleda izvođača u baletu valja tumačiti kao premisu da nisu sva tijela sposobna ili predodređena plesati balet. Tijelo koje ne odgovara zahtjevima koje postavljaju institucionalizirana plesna tehnika, filozofija i politika vrlo često neće ni dobiti priliku usvajati plesnu obuku. (Katarinčić 2013a: 71)

Drugim riječima, mogućnost pristupanja baletnom školovanju ovisit će o određenoj (estetskoj ili funkcionalnoj) fizičkoj osobini koja djetetu može, ali i ne mora biti prirodno dana. Prema Sadono, baletne su dvorane još uvijek ispunjene genetski privilegiranim plesačima koji na taj način tvore "genetski bazen" (Sadono 1998: 34).

\section{POTRAGA ZA IDEALNIM BALETNIM TIJELOM}

Postavlja se, dakle, pitanje koji su to kriteriji prema kojima se procjenjuju predispozicije djeteta pri upisu u baletnu školu. U knjizi Alphabet of Classical Dance navedene su sve

\footnotetext{
ljanje tijelom ključno za stjecanje socijalnog statusa, kao i s kulturnim kapitalom, pri čemu određeni tip tijela nosi više kulturne vrijednosti u određenom kontekstu (Bourdieu u Pickard 2015: 30).

${ }^{9}$ Prema Kelly (u Pavičić Vukičević 2013: 121), pojam skrivenog kurikuluma odnosi se na vrijednosti koje učenici u školi nauče zbog načina na koji se u školi planira i načina na koji je škola organizirana. To obuhvaća i društvene i spolne uloge, stavove, vrijednosti, pozicije moći, hegemonijski diskurs i druge aspekte življenja koji se neosviješteno prenose iz generacije u generaciju kao samorazumljive, neupitne, općekulturne i trajne činjenice.
} 
predispozicije koje su potrebne za upis, ${ }^{10}$ a slični kriteriji primjenjuju se u gotovo svim tradicionalno orijentiranim baletnim školama u svijetu. Dio navedenih predispozicija struka pravda zahtjevnošću same tehnike klasičnog baleta koja je predviđena za idealna (baletna) tijela te smatra da upravo iz tog razloga treba biti pažljiv prilikom probira djece pri njihovu upisu u baletnu školu, što je argument koji se donekle može prihvatiti. Ipak, nemoguće je ne primijetiti kako se kriteriji gotovo isključivo odnose na fizičke karakteristike pri čemu se velika većina njih odnosi upravo na estetske karakteristike, odnosno na sam izgled tijela. Ta usmjerenost isključivo na fizički kapital, tj. na tijelo i njegovu estetiku osnovni je problem koji ističu mnogi teoretičari koji se bave ovim područjem.

Naglašavanjem isključivo tijela stvara se dojam tijela kao objekta bez osobnosti. Međutim u baletu se upravo na temelju fizičkih predispozicija dodjeljuje vrijednost plesaču, odnosno njegovom tijelu. Tijelo je ono koje nosi i sadrži vrijednost. Vrednuje se ponajprije fizički kapital. (Katarinčić 2013a: 71)

lako je baletna umjetnost čvrsto određena tradicijom čiji je školovanje neizostavni dio, čini mi se kako je krajnje vrijeme da se i tradicija kao i već spomenuta baletna ideologija ozbiljno dovedu u pitanje. Naime, sagledavajući prakse pri selekciji i odabiru baletnih tijela iz pedagogijske perspektive, možemo reći kako su one nesumnjivo diskriminatorne budući da pravo na umjetničko obrazovanje u baletnoj umjetnosti imaju samo djeca s određenim fizičkim/estetskim karakteristikama. Ovdje želim dodatno objasniti zašto smatram da fokus na provjeru fizičkih/estetskih karakteristika pri upisu u baletnu školu treba promatrati kao diskriminatornu praksu. Naime, prema Ani Širanović,

diskriminacija se definira kao bilo kakvo različito postupanje - isključivanje, ograničavanje, davanje prednosti, koje se temelji na rasi, boji kože, etnicitetu, spolu, jeziku, religiji, uvjerenju, porijeklu, imovini, statusu rođenja i nekom drugom faktoru ili statusu, s namjerom odnosno posljedicom osporavanja ili ometanja priznanja i ostvarivanja prava i sloboda. (UNICEF 2007 u Širanović 2016: 72)

Također, prema istoj autorici, upravo su škole i druge odgojno-obrazovne institucije kao državne institucije u tom smislu "dužne biti mjesta nulte tolerancije na diskriminaciju" (Širanović 2016: 72) što, između ostaloga, podrazumijeva i "propitivanje, raspravljanje i prema potrebi korigiranje ukorijenjenih stavova i uvjerenja" (ibid.: 73), što je izuzetno važno u kontekstu baletnih škola. Pritom Širanović kao jedan od ključnih faktora vidi osvještavanje nastavnika te smatra kako je u borbi protiv diskriminacije ključna dispozicija učitelja i drugih odgovornih odraslih upravo - osjetljivost na diskriminaciju (ibid.). Stoga je jedan od osnovnih ciljeva ovog rada osvještavanje diskriminatornog karaktera selekcije

\footnotetext{
${ }^{10}$ Kao osnovne karakteristike navedene su: odgovarajuća visina (ni ekstremno niski ni ekstremno visoki) tjelesne proporcije; mala glava, dugi vrat (u odnosu na ostatak tijela), mala prsa, lagano zaobljena ramena šira od kukova, ravna leđa, uzak struk, ni predugačak ni prekratak torzo (u odnosu na ostatak tijela), malena stražnjica, duge ruke i šake, simetrične i ne pretjerano naglašene lopatice, duge ravne noge s relativno velikim rasponom, uski gležnjevi i duga stopala. Također, potencijalni učenici moraju imati dobru mobilnost zglobova, izražen rist i svod tabana, prirodno otvorene kukove, koljena i stopala, prirodnu sposobnost za skokove, vrteške i mogućnost ekstremne razgibanosti (Bazarova i Mei 1973).
} 
djece temeljene na estetskim karakteristikama. Naime, iako baletne škole takav način probira (pretpostavljam) pravdaju zahtjevima baletne profesije koja estetske kriterije ima utkane duboko u svojim temeljima te vjerojatno ne postoji respektabilnija baletna škola u svijetu koja nema audiciju temeljenu na fizičkim/estetskim predispozicijama, ne smijemo izgubiti iz vida da se u ovom slučaju ne radi o odraslim ljudima, koji mogu ili ne moraju pristati na takve kriterije, već se radi o djeci. Drugim riječima, najbolji interes djeteta u obrazovanju, koji uvijek mora biti u fokusu pedagoškog djelovanja, isključuje mogućnost selekcije, a posljedično i evaluacije djeteta prema estetskim kriterijima. Naime, takvi kriteriji, uspostavljeni na audiciji, s vremenom formiraju dominantni obrazac koji se ogleda i u skrivenom kurikulumu škole, a prema kojem se djeca nastavljaju procjenjivati tijekom cijelog školovanja. Tako se o djeci razgovara kao o "lošem materijalu”, "debeloj djeci", "problematičnim tijelima", "ružnim tijelima” i slično, bez "propitivanja, raspravljanja i prema potrebi korigiranja ukorijenjenih stavova i uvjerenja” (ibid.: 73). Izuzetno je važno naglasiti da estetske karakteristike tijela ni na koji način nisu povezane sa sposobnošću izvođenja baletnih koraka te, u tom smislu, ne bi smjele biti ni postavljene kao kriterij. Upravo zato je izuzetno važno razvijati osjetljivost na diskriminaciju, o kojoj govori Širanović, kroz kritičku analizu nekih od temeljnih i općeprihvaćenih praksi u baletnoj umjetnosti. Jedino će se tako praksa selekcije i procjenjivanja djece prema estetskim karakteristikama početi ozbiljnije preispitivati i u tradicionalno orijentiranim školama u kojima je ta tema još uvijek tabu.

Osobno, cijeli sam se život smatrala izuzetno privilegiranom jer sam odmalena voljela balet, a isto tako, iz moje perspektive i balet je volio mene. Svoju poziciju, najbolje među odabranima, doživljavala sam kao iznimnu sreću. U mojem je slučaju bila zadovoljena velika većina kako fizičkih tako i estetskih karakteristika te me se percipiralo kao "talentirano" tijelo, tj. tijelo koje je "sposobno" za balet. Međutim, tjelesni razvoj djeteta nije linearan te ono na svom putu do zrelosti prolazi kroz mnoge promjene od kojih neke mogu presudno utjecati na njegovu profesionalnu baletnu budućnost. Kako dijete raste, prvi utisci o njegovu izgledu mogu se promijeniti te se, nekada obećavajući fizički izgled, može transformirati u nešto (u baletu) neželjeno (Midtgaard 2016: 31). Naime, trenutak u kojem dječje tijelo dobiva npr. ženske atribute kao što su bokovi ili jedan od najvećih krimena u baletnom svijetu - grudi, može u potpunosti izmijeniti djetetovu tjelesnu građu koja je dotad bila baletno/estetski prihvatljiva. "Obećavajuća karijera može biti prekinuta povredom ili promjenom tijela u pubertetu, npr. ukoliko se grudi previše razviju. Neke od plesačica [...] izražavaju se o svojim tijelima kao 'neproblematičnim', dok su druge ozbiljno patile tijekom godina školovanja” (Alten 2002: 50). Moje relativno "neproblematično" tijelo u pubertetu je dosegnulo visinu od $175 \mathrm{~cm}$, što je više od onoga što je u baletu prihvatljivo, $i$ bokove koji su najednom postali jednako široki kao i ramena. U mom slučaju to nije bitnije narušilo estetiku tijela. Međutim, nekolicini mojih kolegica "dogodile" su se upravo grudi čime je značajno umanjen njihov fizički kapital, a nekima je upravo ta tjelesna promjena odredila profesionalnu budućnost.

O zdravstvenom aspektu potrage za "idealnim baletnim tijelom" govori i Justin Howse, ortopedski kirurg, koji se između ostaloga posvetio istraživanju uklanjanja uzroka uobiča- 
jenih povreda na području baletne umjetnosti. Prema Howseu, današnje škole imaju dva izbora: ili će se odlučiti za princip rigorozne selekcije u kojem će odabirati samo manji broj djece s idealnim predispozicijama koja će u kombinaciji s dodatnim pripremnim vježbama moći pratiti zahtjevan program škole, ili će prihvatiti manje "zadovoljavajuća tijela" za koja će se onda morati napraviti određeni "ustupci" u primjeni tehnike koja se poučava (Howse 2000). Također, izostanak "idealnog baletnog tijela" vjerojatno će značiti da osoba ne može, kao svoj cilj, ostvariti karijeru profesionalnog plesača klasičnog baleta, ali se može plesno obrazovati te nastaviti karijeru u nekoj drugoj vrsti plesne umjetnosti ili može postati npr. baletni učitelj kao i teoretičar plesa.

\section{OPRESIJA I AUTORITARNOST U PEDAGOŠKIM PRAKSAMA BALETNOG ŠKOLOVANJA}

Tijekom cijelog svog školovanja, ali i profesionalne karijere, vrlo sam jasno naučila jednu činjenicu - moja izvedba uvijek može (i mora) biti bolja. To se jasno očitovalo kroz komentare i korekcije koje su mi baletni majstori upućivali nakon predstave, želeći mi pomoći da već na sljedećoj izvedbi ispravim pogrešno izvedene korake. Te korekcije su, ovisno o njihovu broju i tonu kojim su izrečene, bile putokaz prema kojem sam i sama procjenjivala vlastitu izvedbu. S jedne strane, takav pristup znači kako uvijek postoji prostor za napredak te kako se predanim vježbanjem moguće približiti željenom cilju. S druge strane, to isto tako znači da nikada nije dovoljno dobro. Ta neprestana potraga za savršenstvom koje je nemoguće dostići, izloženost kritici te unificirano i nerealno postavljeni ciljevi ključno su utjecali na manjak samopouzdanja s kojim sam se borila sve do zrelih godina. Preispitivanje nakon svake predstave, memoriranje pogrešaka, kako ih ne bih ponovila te kako bi sljedeći put moj nastup (možda) bio savršen, utjecali su i na osjećaj konstantnog nezadovoljstva vlastitim izvedbama. Umjesto uživanja u plesu, u mene se uvukao strah od pogreške te sam se kroz cijelu karijeru borila s intenzivnom tremom koja je uvelike otežavala moje nastupe. Još i danas, trideset godina nakon početka profesionalne karijere, živo se sjećam svake važnije izvedbe kao i pogrešaka koje sam tijekom tih izvedbi napravila. Tek prije nekoliko godina, odgovarajući na novinarsko pitanje o tome što sam kroz karijeru i godine života naučila, shvatila sam da je možda najvažnije to što sam si naučila oprostiti. Izjava jedne od najvećih balerina dvadesetog stoljeća Natalije Makarove pokazuje kako jednake stavove o vlastitim izvedbama imaju i oni najveći: "Nije moguće biti savršen uvijek možeš biti bolji. Ja nikada nisam ponosna i zadovoljna s onim što sam učinila. Tek ponekad se ne sramim" (Makarova u Lawrence 2012). Negativni stavovi i nemogućnost objektivne procjene vlastite izvedbe te nisko samopouzdanje samo su neke od posljedica neprimjerenih pedagoških praksi koje se primjenjuju u baletnom školovanju. Upravo zbog posljedica koje takav način razmišljanja ima na mlade plesače važno je promotriti kojim se sve suptilnim opresivnim mehanizmima stvara i održava.

Kada se pobliže promotre i upoznaju metodika i sustav podučavanja u baletu, nailazi se na vrlo rigorozne, moralno upitne i zacijelo neprimjerene mjere za zdravlje duha, osob- 
nosti, pouzdanja osobe, a posebno djeteta na kojemu se metode počinju primjenjivati, a koje ono usvaja i prihvaća kao "normalne". (Katarinčić 2013a: 76)

Prema Johnston, tradicionalna, autoritarna baletna pedagogija ima izuzetno visoku razinu očekivanja od učenika koja je u nerazmjeru s niskom razinom učiteljeve topline i suosjećajnosti (Johnston u Yamashita 2013: 4). Takav autoritaran odnos, tj. stil podučavanja u teorijskom je smislu opisan u knjizi Teaching Physical Education, u kojoj autori, Muska Mosston i Sara Ashworth, predstavljaju "teoriju spektra" te diferenciraju stilove podučavanja prema različitim ulogama koje u njima imaju učitelj i učenik, ovisno o tome tko donosi odluke u procesu učenja/podučavanja. Prvi u spektru reproduktivnih stilova koji se, prema autorima, često koristi upravo u "podučavanju plesnih tehnika, prvenstveno u baletnoj umjetnosti je tzv. naredbodavni stil"11 (Mosston i Ashworth 2008: 87). Autori ga opisuju kao stil u kojem autoritarna figura, tj. učitelj donosi sve odluke dok je učenik onaj koji sluša i slijedi. "Jedina odluka koju učenik može donijeti u naredbodavnom stilu je izbor između ‘da, učinit ću to’ ili 'ne, neću to učiniti”' (ibid.: 80). lako i sami autori naglašavaju kako je naredbodavni stil samo jedan od stilova u spektru te ga je nakon nekog vremena poželjno nadopunjavati drugim stilovima, čini se kako je upravo taj stil, svjesno ili nesvjesno, najzastupljeniji u baletnim dvoranama. Prema Mosstonu i Ashworth, ni jedan stil nije i ne može biti ni pozitivan ni negativan sve dok se vodi računa o tzv. specifičnostima stila. Tako učitelj, u situaciji u kojoj ima apsolutnu moć i donosi sve odluke, mora provoditi podučavanje uz obostrano poštivanje, osiguravajući učeniku emocionalnu sigurnost, toplinu i podršku tijekom cijelog procesa. U suprotnom, učitelj zlorabi svoju moć te kontrolira učenika, koreći ga i kažnjavajući zbog pogrešaka, što kod učenika izaziva otpor u procesu podučavanja (ibid.: 88).

Zbog svega navedenog postavlja se pitanje - postoji li i u kojoj mjeri u nastavi klasičnog baleta svijest o postojanju kao i o upotrebi različitih stilova podučavanja? Naime, činjenica da u nečijem radu primjećujemo značajke određenog stila uopće ne mora govoriti o svjesnosti njegove primjene. Takav nedostatak svijesti o vlastitom radu te nepoznavanje teorijskih polazišta donosi i nemogućnost evaluacije, pa tako i unapređenja pedagoških praksi kroz nadogradnju i razvoj određenog sila, ali i uklanjanja mogućih pogrešaka. Na taj se način propušta dragocjena mogućnost da se uobičajeni i u baletnoj nastavi najčešće prepoznat naredbodavni stil podučavanja razvije i nadogradi nekim od stilova reproduktivnog spektra te da se razmotri na koji se način neravnoteža u donošenju odluka u procesu podučavanja može ublažiti. Naime, nekritička upotreba naredbodavnog stila u sebi skriva mnoge opasne zamke te bi trebalo početi ozbiljno razgovarati ne samo o ishodima koji se tim stilom efikasno postižu već i o posljedicama koje učinjene pogreške mogu ostaviti na učenike. Prema Yamashiti, takva neravnoteža moći tipična je za mnoge plesne dvorane iako ima različite stupnjeve. Posve je jasno kako postoje nastavnici baleta koji nisu grubi, bezobrazni i zahtjevni, no visoka očekivanja, dinamika rada te uloga vizualnog (estetike) su više-manje svugdje u baletu isti (Yamashita 2013: 4).

${ }^{11}$ Naredbodavni se stil preporučuje kod učenja vještina kod kojih je potrebna preciznost, ujednačenost, u kojima postoji visoki faktor rizika ili kod aktivnosti koje imaju izrazito kompetitivan karakter. 
Analizirajući karakteristike naredbodavnog stila podučavanja koje u svojoj knjizi nude Mosston i Ashworth čini se kako ih možemo povezati s onime što Paolo Freire u svojoj knjizi Pedagogija obespravljenih naziva "bankarskim" konceptom obrazovanja. Prema "bankarskom" konceptu, učitelj poučava učenike koristeći autoritarnu poziciju onoga koji posjeduje znanje dok je opseg aktivnosti učenika ograničen na primanje i pohranjivanje znanja. Osnovni problem “bankarskog” koncepta obrazovanja, prema Freireu, leži u potpunoj neravnoteži odnosa pri čemu se učenik pasivizira te postaje sve skloniji prilagoditi se svijetu takvom kakav jest i prihvatiti iskomadanu sliku stvarnosti kakva je u njega pohranjena (Freire 2002: 58-59). Ako, prema Clement, Freireov bankarski model prebacimo na područje plesa, dobivamo situaciju u kojoj se proces podučavanja odvija kroz transmisiju znanja te reprodukciju uspostavljenih "istina” pri čemu učenici uče jedino imitirati i memorirati kombinacije pokreta. Također, budući da je učitelj konačni autoritet i primarni/jedini izvor znanja, učenici nisu ohrabreni preispitivati njegove odluke. Oni uče biti tihi promatrači te, budući da ovise o povratnoj informaciji koju dobivaju od vanjskog izvora (učitelja), svakom komentaru ili izostanku komentara pridaju izuzetno velik (preuveličan) značaj (Clement 2007: 34). Prema Shapiro, kod učenika se vrednuje upravo sposobnost da slijedi pravila te replicira setove vještina što dovodi do toga da se plesačko tijelo objektivizira i automatizira (Shapiro 1999: 127). "U baletu je učitelj taj koji posjeduje informaciju. On je taj koji vidi detalj i to je ono što mu daje moć. [...] Učitelj izvodi [nastavu] koristeći učenika kao megafon. Plesač nema što samostalno reći. On je trenirani vojnik koji stupa" (Sadono 1998: 40).

\section{DISCIPLINA ILI "USPJETI U PLESU ZNAČI PATITI U TIŠINI"}

Jedna od najupečatljivijih i možda najčešće spominjanih rečenica u baletnoj dvorani bila je: "Nije tvoje da misliš i govoriš, tvoje je da napraviš petu poziciju." Od baletnih se plesača kako u procesu školovanja tako i u profesionalnom životu očekuje bespogovorna poslušnost koja isključuje svako moguće propitivanje učiteljevih postupaka. Ta "vojnička disciplina" je također i jedna od karakteristika naše baletne zajednice/profesije na koju sam dugo vremena bila najponosnija. Često sam drugima znala objašnjavati kako je takav način ophođenja u baletnoj dvorani apsolutno nužan, a svoju sposobnost da podnesem neprestanu kritiku usmjerenu na sve aspekte mog rada i izgleda doživljavala sam kao vlastitu "supermoć" koja mi osigurava napredak. Tek mnogo kasnije, u profesionalnoj karijeri, postala sam svjesna s koliko je potisnutih frustracija popločen moj uspjeh. "I ja sam, kao i mnoge druge žene živjela svoj profesionalni život, potiskujući svoju bol i sakrivajući otvorene rane čak (a možda i najviše) od same sebe" (Lewis u Bolt 2008: 2).

Disciplina je pojam koji se usko povezuje s baletnom umjetnosti te se ujedno, unutar baletne zajednice, smatra i jednim od njezinih najkorisnijih "nusprodukata". Upravo iz tog razloga izuzetno je važno analizirati što sve u sebi skriva to "kukavičje jaje" umotano u ružičasti til baletne umjetnosti. Disciplina se u baletnim školama očituje kroz apsolutnu poslušnost i pokoravanje idealiziranoj autoritarnoj figuri nastavnika. "Nastavnik je taj koji 
'dekodira' uspostavljenu estetiku i umjetničke zahtjeve plesne forme, čineći samo tako uspjeh učenika mogućim. U tom okruženju učenik se promatra kao "poslušno tijelo"” (Wotten u Bolt 2008: 9). lako je prema Konvenciji o pravima djeteta neophodno poduzeti potrebne mjere kako bi se osiguralo "da se školska disciplina provodi na način kojim se potvrđuje ljudsko dostojanstvo djeteta” (Konvencija o pravima djeteta), baletne škole nažalost nemaju osigurane mehanizme kojima bi se kontrolirao upravo taj aspekt nastave. ${ }^{12}$ Prema Juulu i Jensen, "osobni integritet pojedinog djeteta mora biti važniji od konkretnog pedagoškog cilja. Nitko ne smije odobriti upotrebu pedagoških okvirnih uvjeta, pravila i metoda ako se njima namjerno ili svjesno povređuje djetetov integritet ili njegove granice" (Jull i Jensen 2010: 94). Upravo poimanje discipline kao modela moći izuzetno je zanimljivo u kontekstu klasičnog baleta. Na njega ukazuje i francuski filozof Michel Foucault, koji u svojim radovima redefinira pojam discipline te je vidi kao mehanizam nadzora i kontrole, kroz pogled autoriteta, što nas dovodi do "novog pogleda na tijelo kao na nešto što bi se moglo trenirati i oblikovati. Disciplina se provodi nad tijelom i kroz tijela pa to rezultira ne samo produktivnim i korisnim tijelima već i pokornim, poslušnim subjektima koji se samoobuzdavaju i samodiscipliniraju" (Malcolm u Biti 2012: 69). Prema Foucaultu,

tijelo u sportu [pa tako i u baletu] doista funkcionira kao predmet i meta moći - njime se manipulira, oblikuje ga se, ispravlja, pokorava, umnogostručuju mu se snage. Disciplina dakle, uvećava snage u tijelu u ekonomskim terminima korisnosti, dok te iste snage umanjuje u političkim terminima poslušnosti. (Foucault u Biti 2012: 98-99)

"Samoobuzdavanje i samodiscipliniranje" poslušnog baletnog tijela najjasnije se očituje u tišini baletne dvorane u kojoj je učitelj onaj koji govori dok učenici poslušno i bez pitanja reproduciraju naučene korake. U izvrsnom tekstu "Silencing the Silent: A Feminist Analysis of Classical Ballet” feministkinja, plesna pedagoginja i teoretičarka Jennifer M. Bolt obrazlaže percepciju baleta kao "tihe umjetnosti". Tako je, prema Bolt, važno vočiti dihotomiju između "svjesne odsutnosti vokalne ekspresije za vrijeme plesnog čina i psihičkog sputavanja učenika da jasno artikuliraju pitanja kojima se reflektiraju na učenje, posebno ako je nastavnik dominantna snaga u baletnoj dvorani” (Bolt 2008: 7). Baletna ideologija "nametnute šutnje" ne bi se mogla provoditi bez snažnog autoritarnog učitelja koji je dominantna i idealizirana figura u procesu poučavanja, ali i u životu profesionalnih plesača. Mnogi baletni učitelji opravdavaju takvu praksu “utišavanja učenika” naglašavajući kako "u tradicionalnom načinu poučavanja baleta tišina u dvorani pruža priliku stavljanja većeg naglaska i vrijednosti na što brže moguće utjelovljenje pokreta" (ibid.). Nedostatak komunikacije između nastavnika i učenika proteže se i u područje profesionalnog bavljenja baletom. Možemo ga prepoznati u baletnoj dvorani, u dnevnim rutinama u kojima se plesačka poslušnost koristi kao sredstvo za "utišavanje" (Devald Roksandić 2016: 21). Prema Christopheru Hampsonu, ravnatelju škotskog baleta, problem discipline, koja je ključna i pri treningu profesionalnih plesača, je da ona pasivizira plesače. "Ako je netko odmalena

${ }^{12}$ Ovdje prvenstveno mislim na baletne škole u Republici Hrvatskoj koje, koliko je meni poznato, nemaju zaposlenog pedagoga kao stručnog suradnika koji bi mogao provoditi pedagošku evaluaciju nastave te davati smjernice i sugestije nastavnicima baleta kao i ukazivati na moguće propuste. 
treniran isključivo tako da poštuje učiteljevu riječ i pokušava tijelo podčiniti određenom idealu, taj se kasnije spreman odreći svojeg samopoštovanja i samoodređenja" (Hampson u Mackrell 2018: 3). Rečeni proces u kojem se potiče submisivnost te se balerina percipira kao objekt koji samo "šuti i radi" i koji nema pravo postaviti pitanje dovodi do toga da "plesači stječu dojam da nije važno što oni sami misle jer ih se i ne pita za mišljenje, a u svom su vježbanju naučeni ne komentirati, ne prigovarati, ne pitati, nego usvajati i biti poslušni” (Katarinčić 2013a: 76). Prema Bolt, "kao učenici mi jednostavno prihvaćamo autoritarnu atmosferu kao normalan dio plesnog treninga" (Bolt 2008: 11).

U četvrtom razredu srednje baletne škole pripremala sam se za Jugoslavensko natjecanje baletnih škola i završni ispit, za što me uvježbavala baletna majstorica iz bivšeg Sovjetskog Saveza, koja je surađivala s baletnom školom kao vanjski stručni suradnik. Priprema za natjecanje provodila se $u$ obliku individualne nastave u kojoj smo nas dvije cijelo vrijeme bile same u dvorani. Imala sam sedamnaest godina i nisam govorila ruski jezik dok je ona govorila - isključivo ruski jezik. Naravno, ništa je nisam razumjela. Nekoliko sam joj puta pokušala ljubazno objasniti da ne razumijem što su to "spina", "padjom", "talja" i "pah", ali svako moje pitanje tumačila je kao neposlušnost. Sve što sam u tom trenutku željela je - pokazati joj da zavrjeđujem njezinu pozornost, ali zbog silnog uzbuđenja i potpunog nerazumijevanja onoga što mi govori griješila sam i pri najjednostavnijim koracima. Nakon moje greške, nerazumijevanja i našeg nesporazuma poslala bi me u kut dvorane da samostalno uvježbavam korak koji mi nije išao, a ona bi me ignorirala. Nakon nekog bi me vremena ponovno pozvala k sebi i sve bi krenulo ispočetka, do sljedećeg nerazumijevanja s moje strane. Nakon svakog sata sam plakala, potpuno izluđena tom bujicom ruskih povika i negodovanja iz kojih sam prvo počela prepoznavati riječi "ljenjivaja" i "bezobrazje". Ona je smatrala kako ću je, ako zaista želim s njom raditi - moći razumjeti. Nakon tjedan dana sam je zaista i razumjela. Ovdje moram napomenuti kako sam s tom baletnom majstoricom nastavila surađivati kroz cijelu karijeru te kako me izuzetno puno naučila za što sam joj i danas - iznimno zahvalna. Sve svoje najveće uloge napravila sam uz njezino vodstvo i jedino sam se radeći s njom osjećala sigurno na sceni. I da, danas odlično govorim ruski jezik!

O specifičnom karakteru odnosa nastavnika i učenika u baletu Bolt svjedoči: "Što sam bila starija i što sam dulje radila s njom, njezina je disfunkcionalna snaga postajala ključ moga uspjeha. Ona je bila 'master teacher' čija je hegemonijska snaga normalizirala disbalans snaga među nama” (Bolt 2008: 11). Taj intenzivan odnos s učiteljem s vremenom postaje gotovo ovisnički te učenik, na koncu, u potpunosti gubi samostalnost i sposobnost samoprocjene. "[P]lesna su tijela izrazito izložena pogledima (i procjenama) koreografa, učitelja, ali i publike te često njima i definirana. (Scenskim) izlaganjem vlastite tjelesnosti ona postaju objektima podložnijima društvenim interpretacijama i tuđim procjenama" (Katarinčić 2013b: 299-230). Budući da sav sud o vašem radu konstantno donosi netko drugi, potrebne su godine osnaživanja kako biste mogli preuzeti ponovnu kontrolu nad tim dijelom svojeg života i odgovoriti na jednostavno pitanje - kakva je bila moja večerašnja izvedba? ${ }^{13}$

${ }^{13} \mathrm{Ni}$ desetak godina nakon završetka školovanja nisam bila u stanju samostalno procijeniti kvalitetu vlastite izvedbe. Tu procjenu je za mene uvijek donosila osoba s kojom sam u tom trenutku radila. To je u ba- 


\section{OSVJEŠTAVANJE POTLAČENIH}

Nakon svega iznesenog u ovom radu nameće se pitanje - što je to što koči promjene u baletnoj zajednici? Naime, svi teorijski tekstovi koje sam konzultirala pišući ovaj rad opisuju pedagošku stvarnost u baletnoj dvorani kao autoritarnu praksu, visoko neujednačenih odnosa moći, u kojoj se diskriminacija temeljena na fizičkom izgledu opravdava specifičnošću profesije. Takvi obrasci "zasađeni” u baletnom školovanju oblikuju i profesionalnu svakodnevicu u kojoj prevladavaju disciplina, poslušnost, šutnja i konformizam. lako Hampson smatra kako nove, "prosvijetljene" generacije plesača opresivne prakse u baletnoj dvorani sve češće proglašavaju nekreativnim i štetnim (Hampson u Mackrell 2018: 2), njihova je prisutnost još uvijek evidentna. U tom smislu može se reći kako velika prepreka, ali i potencijal za promjenu leži i u samim plesačima koji često ne pronalaze snagu za suprotstavljanje raznim opresivnim mehanizmima s kojima se susreću. Paolo Freire, u svojoj knjizi Pedagogija obespravljenih takav fenomen naziva "strah od slobode" (Freire 2002: 37). Prema Vican, Freire pedagogiju promišlja u ime obespravljenih, a moguće ju je ozbiljiti samo s njima. Njezinu rođenju oni mogu pridonijeti samo ako shvate da "tlačitelja nose u sebi" (ibid.: 17). Tako možemo reći da je tlačitelj u biće plesača ucijepljen tijekom procesa školovanja autoritarnim praksama discipline, šutnje i poslušnosti, a tijekom profesionalne karijere nastavlja rasti i potvrđivati se samodiscipliniranjem i autocenzurom mišljenja. Tlačitelj u nama predstavlja sve ono što nam je poznato, prakse, propise i pravila unutar kojih se snalazimo i koje smo usvojili kroz školovanje i karijeru. Iskorak izvan poznatog teritorija donosi izazove za koje plesači često nisu spremni. "Obespravljeni se, nakon što su internalizirali sliku tlačitelja i prihvatili njegove upute, boje slobode. Sloboda od njih zahtjeva odbacivanje te slike i njeno zamjenjivanje neovisnošću i odgovornošću" (Freire 2002: 38). Prema Frommu, "jedno biće je za sebe samostalno tek onda kada stoji na vlastitim nogama, a na vlastitim nogama stoji tek onda kad svoje postojanje zahvaljuje samome sebi" (Fromm 1984: 118). U kontekstu baletne umjetnosti plesači svoje postojanje uvijek i bez iznimke zahvaljuju svojim učiteljima. ${ }^{14}$

Potlačeni koji su prihvatili strukturu dominacije i ostali ravnodušni, osjećaju se sputanima i ne mogu započeti borbu za slobodu sve dok nisu u stanju preuzeti rizik koji ta borba zahtijeva. Štoviše, njihova borba za slobodu ugrožava ne samo tlačitelja već i obespravljene kolege koji se boje još većeg ugnjetavanja. (Freire 2002: 38)

\footnotetext{
letu u jednoj mjeri i razumljivo stoga što plesač ne može u potpunosti biti svjestan svih (pogotovo estetskih) aspekata svoje izvedbe. Ipak, apsolutna nemogućnost procjene vlastite izvedbe predstavlja veliki problem i direktno je vezana uz autoritarne pedagoške prakse koje za posljedicu imaju nedovoljnu samostalnost i samosvijest učenika.

14 "Kult zahvalnosti" sastavni je segment ovisničkog odnosa koji učenik razvija prema "idealiziranoj autoritarnoj figuri" učitelja, a povezan je s percepcijom učitelja kao osobe koja u svojim rukama drži ključ učenikove profesionalne budućnosti. Tako cijeli život ostajemo "ucijenjeni” osjećajem iznimne zahvalnosti prema onima koji su omogućili naš uspjeh što nas sprečava da se kritički odredimo prema samom putu do uspjeha i karakteru dobrih namjera kojima je popločen. Pišući ove redove ne mogu se osloboditi iracionalnog osjećaja grižnje savjesti stoga što, relativno javno, kritički progovaram o osobama koje su najzaslužnije za moj profesionalni uspjeh i kojima ću za to zauvijek biti zahvalna.
} 
Shapiro objašnjava kako je jedna od najvažnijih zadaća plesnih pedagoga "dati glas" učenicima. "Međutim ne mogu im ja 'dati glas'. Oni to moraju učiniti sami, prepoznajući i imenujući forme tlačenja i oslobođenja” (Shapiro 1999: 148).

\section{DIJALOG SA SOBOM}

Obespravljeni su istodobno i potlačeni i tlačitelji čiju su svijest internalizirali. Sukob je u izboru: biti potpuno svoj ili u sebi podijeljen, podvojen, odbaciti tlačitelja ili ne, prikloniti se ljudskoj solidarnosti ili otuđenju, slijediti propise ili imati pravo odabira, biti promatrač ili sudionik, djelovati ili imati iluziju o djelovanju preko aktivnosti tlačitelja, glasno govoriti ili šutjeti, biti osakaćen, onemogućen stvarati, obnavljati i mijenjati svijet. (Freire 2002: 39)

....prve su nevolje počele vrlo brzo. Djevojke iz ansambla su pričale kako je grub na probama, kako nema strpljenja, kako mijenja raspoloženje u trenu i ne preza ni od najslikovitijih uvreda. Vjerojatno je imao loš dan, na mojim probama je bio divan.

Sve češće su s proba izlazile uplakane i izmrcvarene, psihički i fizički. Balet je takav posao, težak i okrutan, a i nije za svakoga, treba to moći izdržati.

Moja najbolja prijateljica imala je pravi emotivni slom i kroz suze je govorila kako više ne može i kako će sigurno dati otkaz. Pretpostavljam da je poludio na nju jer nije dobro izvela korak. Trebala bi se još više potruditi. On ne viče na one koji se trude. Na mene nikada ne viče.

Sve se više počinje govoriti o maltretiranju i zlostavljanju. Strah u zraku se mogao namirisati. ...ali ostvarujemo sjajne rezultate, predstave su nam izvrsne, interes za balet nikada nije bio veći, nije li to ono što smo svi htjeli?

Izbio je javni skandal, mediji ${ }^{15}$ su objavili popis uvreda koje su korištene $u$ baletnoj dvorani. Sve je proglasio lažima, a one koje su imale hrabrosti istupiti u javnosti nazvao je lijenima i nesposobnima.

To što drugi nemaju [moć, znanje] znači da su ti drugi nesposobni i lijeni, a najgora je njihova neopravdana nezahvalnost prema "velikodušnosti" vladajućih. Upravo stoga što su "nezahvalni" i "zavidni" obespravljeni se smatraju potencijalnim neprijateljima koje valja držati na oku. (Freire 2002: 47)

\footnotetext{
${ }^{15}$ Mirjana Dugandžija, “Oluja nad labuđim jezerom”, Globus, 2003., 58-62.; Helena Braut, “Čija je uvreda teža”, Vjesnik, 2003., 16.; Martina Kalle, “Toleriranje grubosti ili strah od otkaza”, Vjesnik, 2004., 15.; Paula Bobanović, "Dinko Bogdanić me je fizički napao i vrijeđao”, Extra, 2004, 16-18.; "Kronika skandala u nacionalnoj kući”, Jutarnji list, 2004, 71-73.
} 
Situacija se pogoršala do neizdrživosti. Ja to zaista nisam vidjela na svoje oči, to se ne događa na mojim probama, pa o tome ne mogu ništa reći. Ja sam izuzetno zahvalna za sve što mi je dao. "Zahvalna sam što mi je omogućio da pomaknem vlastite granice."16

Bili smo svi zajedno na probi, i ansambl i solisti.

Nije bio zadovoljan načinom na koji su djevojke stajale $u$ dijagonali.

Nije bio zadovoljan ni nakon što su to ponovile.

Nije bio zadovoljan ni nakon sljedećeg pokušaja...

Morale su stajati u pozi, a da se ne pomaknu...

Deset dugih minuta. U tišini. Za kaznu. Moje prijateljice.

Vidjela sam. Bila sam ondje. Imam odgovornost. Sudjelujem.

Oslobađanje je dakle, bolno rađanje. Ličnost koja se iz toga rodi nova je osoba... (Freire 2002: 39).

\section{POTRAGA ZA "PEDAGOŠKIM" U BALETNOJ PEDAGOGIJI}

Nakon svega iznesenog u ovom radu, želim ispitati posjeduje li pedagogija potencijal promjene kojim može unaprijediti proces baletnog školovanja uvažavajući pritom njegove specifičnosti. Jednostavnije, ovo se pitanje može artikulirati i kao potraga za "pedagoškim" $u$ baletnoj pedagogiji. Dakle, ako fokus vratim na pedagogijsku perspektivu iz koje sam i krenula u pisanje ovog rada te apostrofiram baletno školovanje kao odgojno-obrazovni proces, onda se može reći kako upravo unapređivanje odgojne dimenzije nastave klasičnog baleta ${ }^{17}$ kroz osviješteno pedagoško vođenje može mladim plesačima uvelike pomoći da izrastu u cjelovite i zrele osobe, spremne za sve izazove koje pred njih donosi profesionalni život te se upravo u tom pristupu očitava doprinos "pedagoškog" u baletnoj pedagogiji. Pedagoško vođenje tradicionalno se u pedagogiji objašnjava u okviru pedagoškog odnosa između djeteta, odrasle osobe i sadržaja odgoja i obrazovanja (Širanović 2017: 145). Smatram kako upravo artikulacija pedagoškog odnosa kao neizostavne komponente u procesu baletnog školovanja u najvećoj mjeri može redefinirati odnos između nastavnika i učenika. Naime, pedagoški se odnos svojim obilježjima idealno uklapa u specifičan proces baletnog podučavanja jer omogućuje nastavniku i učeniku uspostavljanje odnosa na novim temeljima, kroz pedagoško poznavanje i razumijevanje djeteta dok istovremeno omogućuje baletu da ostane balet.

\footnotetext{
${ }^{16}$ Rečenica koju sam izgovorila na dodjeli Nagrade hrvatskog glumišta 2004. godine, kada sam primila nagradu za glavnu žensku ulogu u baletu Giselle.

17 “Pod odgojem se najopćenitije misli na a) cjelokupni proces razvoja čovjeka kao ljudskog bića odnosno proces razvoja čovjekove osobnosti (osobnost = karakter, moralni karakter), ali i b) jedan od značajnih, nužno ne i presudnih socijalnih čimbenika u razvoju osobnosti” (Bašić 1999: 177).
} 
Pedagoški se odnos definira kao "poseban međuljudski odnos koji se uspostavlja radi pomoći i podrške djeci i mladima kako bi oni mogli optimalno razviti svoje prirodne (ljudske) mogućnosti" (Bašić 1999: 180). Predstavljajući pedagoški odnos kao hijerarhijski/generacijski odnos (Bašić 2009: 31), važno je istaknuti da nije riječ o hegemonijskoj zloupotrebi hijerarhije, nego o različitoj odgovornosti za (međusobni) odnos koju u procesu nastave razvijaju nastavnik i učenik. Naime, "za kvalitetu odnosa i njegove posljedice isključivu odgovornost snose odrasli” (Jensen i Jull u Bašić 2009: 37). Razmatrajući etički aspekt asimetrije odnosa odrasli-dijete Jensen i Jull uvode pojam ravnopravnog dostojanstva što znači da se objema stranama u odnosu daje ista ljudska vrijednost i iskazuje jednako poštovanje, iako se razlikuju po statusu i moći te nisu ni ravnopravni ni izjednačeni (Juul i Jensen 2010: 221). lako pojam ravnopravnog dostojanstva nije integralni pojam pedagoškog odnosa, on s njime sadržajno korespondira te može predstavljati kvalitativni temelj za ublažavanje/razumijevanje njegove hijerarhije. Jednako tako, baletno školovanje, obilježeno autoritarnim naredbodavnim stilom, može na osnovi ravnopravnog dostojanstva graditi nove temelje međusobnog uvažavanja učitelja i učenika. Naime, činjenica je da je znanje, pogotovo na početku baletnog školovanja, vrlo egzaktno i da je učitelj taj koji ga posjeduje i prenosi što mu daje moć pri donošenju odluka. Međutim, upravo kroz koncept ravnopravnog dostojanstva moguće je drugačije artikulirati asimetriju tog odnosa. "Ravnopravno dostojanstvo u odnosu temelji se na uzajamnosti. To znači da jedna strana ne može unaprijed postaviti pravila kod kojih postoji rizik da bi mogla povrijediti integritet druge strane" (ibid.).

Osim koncepta ravnopravnog dostojanstva, kao temelja odnosa, ključnim smatram obilježja pedagoškog odnosa koja mogu donijeti smjernice u novom promišljanju baletne nastave.

Kao prvo obilježje pedagoškog odnosa i njegovu početnu poziciju, Širanović navodi postojanje pedagoške namjere, odnosno postojanje pedagoške svrhe pomaganja razvoja djeteta (2017: 146). Bašić kaže kako to "implicira povjerenje u mogućnost da odgajanik može razviti svoje potencijale i uspostaviti interakcijski odnos sa svijetom" (1999: 182). Ako potonje transponiramo na područje baletne umjetnosti, ključan je upravo pedagoški optimizam koji se očituje kroz pedagoško povjerenje u učenika i njegove sposobnosti stoga što ono automatski isključuje nepovjerenje uzrokovano djetetovim tjelesnim karakteristikama te podrazumijeva prihvaćanje svakog djeteta koje sudjeluje u procesu baletne nastave. Tako pedagoška namjera koja se legitimira kroz povjerenje dovodi do punog razvoja djetetovih osobnih potencijala bez vobičajene hijerarhijske diskvalifikacije i podjele na one više i one manje talentirane.

Drugo obilježje govori o dvojnom pristupu djetetu, što se $s$ jedne strane odnosi na "poznavanje realnog, stvarnog stanja učenikova razvoja te s druge strane na anticipaciju idealnog-mogućeg stanja učenika, pri čemu se usmjerava odgojno djelovanje" (Širanović 2017: 146). Važno je, prema Nohlu, ta dva cilja promatrati zajedno te kod djeteta "oblikovati one snage koje ono potencijalno ima [...] i voditi ga k uspjehu ne zbog uspjeha samog, nego 
zato što se u njemu ispunjava čovjekov život" (Nohl u Bašić 1999: 183). Ovo je izuzetno važna dimenzija za baletnu nastavu zato što "poznavanje realnog te anticipacija idealnog-mogućeg stanja" dovode u pitanje postavljanje unificiranih ciljeva za svu djecu što je česta praksa u baletnoj umjetnosti. Naime sva su tijela (pa i ona talentirana) međusobno drugačija te imaju neke svoje specifičnosti. Pri podučavanju koraka nastavnik mora voditi računa ne samo o razini idealnog-mogućeg koju dijete može dostići (a koja je kod svakog djeteta drugačija) već i o načinu na koji se to idealno-moguće može postići. Dakle, pedagoško djelovanje u baletnoj nastavi treba biti usmjereno na anticipaciju idealnog-mogućeg stanja svakog pojedinog djeteta, što u baletnu nastavu donosi diferencijaciju u postavljanju ciljeva i odabiru metoda.

Treće obilježje je zastupanje interesa učenika, što obuhvaća posredovanje između učenika i društva/kulture (Širanović 2017: 146). Prema Bašić, izvršavanje te namjere temelji se na etičkoj normi:

raditi za dobro odgajanika, a to znači da djeca i mladi ne smiju nikada postati sredstva koja trebaju služiti za ozbiljavanje određenih [...] interesa. Odgajanje u svakom pogledu treba poslužiti samo unaprjeđivanju razvoja odgajanika, njegovu obrazovanju, a nikada odgajanik ne smije postati sredstvo manipulacije. (Bašić 1999: 183-184)

Upravo u baletnoj umjetnosti djeca često nisu subjekti procesa podučavanja koji se odvija u njihovu najboljem interesu, već postaju sredstvo za reproduciranje i regeneriranje estetskih ideala klasičnog baleta. Prema Nohlu, u pedagoški postupak treba biti ugrađeno pedagoško regulativno načelo izraženo u obliku pitanja: Služe li postavljeni zahtjevi konkretnom djetetu? Jesu li u funkciji njegova razvoja i pridonose li razvoju njegovih mogućnosti? Tko se pedagoški (=odgovorno) ponaša, taj se mora, sukladno tom načelu pitati: ostvaruje li dijete svoje pravo? (ibid.: 184). Kako bi se u potpunosti zastupalo interese učenika koji se reflektiraju u pravima djeteta, potrebno je osvijestiti kako je upravo neadekvatno provođenje autoritarnih pedagoških praksi, opisanih ranije u ovom radu, direktno kršenje tih prava te je suprotno najboljem interesu djeteta.

Odgojni zahtjevi i norme kao promjenjive kategorije četvrto su obilježje pedagoškog odnosa. "Budući da se vrijednosti, znanja, vještine, norme, obrasci ponašanja i značenja tijekom vremena mijenjaju, i samo odgajanje podliježe stalnim promjenama” (ibid.). U tom je smislu područje plesa posebno dinamično područje koje se ubrzano razvija, što predstavlja veliki izazov tradicionalno orijentiranim baletnim školama koje teško prihvaćaju promjene. Promjenjiva kategorija odgojnih zahtjeva i normi samo još snažnije naglašava potrebu za obrazovanjem nastavnika na području baletne pedagogije kao i potrebu za stalnim stručnim usavršavanjem.

Peto obilježje odnosi se na uzajamnost odnosa između odgajatelja i odgajanika. Prema Bašić, odgajatelj nema samo odnos prema odgajaniku nego ima i svijest o odnosu s odgajanikom i on je, za razliku od odgajanika, odgovoran za kvalitetu pedagoškog odnosa. Naime, odgajanik $u$ pedagoškom odnosu nije objekt odgajateljevih namjera i aktivnosti koji samo reagira i prihvaća (ibid.). Svijest o odnosu i njegova kvaliteta je ono što temeljno 
nedostaje baletnom školovanju. Upravo nedostatak svijesti o odnosu uzrokuje opstanak i regeneriranje autoritarnih pedagoških praksi koje pasiviziraju učenika onemogućujući dvosmjernu komunikaciju. Smatram kako je neophodno pronaći prostor/vrijeme na baletnom satu unutar kojega će se osnaživati komunikacija s učenikom kroz pokazivanje interesa za učenikovu perspektivu. Na taj način, prihvaćajući nužnost izražavanja osobnih stavova i mišljenja, šutnja u baletnoj dvorani svest će se samo na "svjesnu odsutnost vokalne ekspresije za vrijeme plesnog čina” bez namjere ušutkavanja i podčinjavanja učenika.

Posljednje, šesto obilježje pedagoškog odnosa govori o autoritetu i slobodnom pristajanju uz autoritet. To se odnosi na slobodno prihvaćanje pedagoškog autoriteta pri čemu se pedagoški autoritet temelji na predanosti pedagoga da uvijek radi za dobro svojih učenika (Širanović 2017: 146). Ako je, prema Bašić, pedagoški odnos uspostavljen s ciljem osamostaljivanja odgajanika i "postavljanja na svoje vlastite noge", onda bi glavna značajka tog odnosa trebala biti stavljanje autoriteta u drugi plan i postupno povlačenje, sve do samog ukidanja potrebe za njim (Bašić 1999: 185). Propitivanje autoriteta i osamostaljivanje učenika, na neki način, predstavlja i centralni dio ovog rada. Prema Bašić, cilj svakog pedagoškog odnosa u konačnici je samostalnost djeteta.

Ako pedagoški odnos teži ukidanju sebe samoga, ako mora pripremiti vlastiti kraj, onda se taj kraj ne razumije kao jednokratni rez [...] nego kao proces u kojemu se mijenja kvaliteta pedagoškog odnosa. Taj odnos prolazi svoju preobrazbu od uzora preko autoriteta do partnerstva. (Bašić 2015: 22)

Upravo u ovim razmišljanjima krije se i najveći izazov koji pedagogija postavlja pred baletnu pedagogiju. To se prije svega očituje u nužnosti inzistiranja na razvijanju učenikove samostalnosti kako bi, na kraju procesa baletnog školovanja, postao cjelovita, zrela i autonomna osoba. Samostalnost izvojevana na kraju tog procesa ublažila bi početnu asimetriju odnosa između učitelja i učenika te omogućila učeniku da na kvalitetan način započne vlastitu umjetničku karijeru.

\section{ZAKLJUČAK}

Je li balet zaista spreman za redizajn i može li se balet drugačije misliti? Danas se baletu pristupa iz različitih perspektiva, temeljito preispitujući hegemoniju u baletnoj dvorani, njegovu autoritarnost i isključivost. Međutim, iako se u tom preispitivanju pojmovi pedagogija i pedagoški često spominju, znanstveni radovi koje sam konzultirala gotovo da i ne koriste izvorne pedagogijske pojmove u svojim analizama. $U$ tom smislu, zanimalo me $u$ kojoj mjeri pedagogijska teorija može doprinijeti procesu podučavanja baleta te postoji li pedagoško/pedagogijsko u baletnoj pedagogiji. Tu vezu pronalazim u naglašavanju važnosti odgojne komponente baletne nastave koja može napraviti pomak od tretmana učenika kao sposobnog tijela koje se disciplinira i trenira prema viđenju učenika kao cjelovite osobe. Osobitu pomoć u toj promjeni pronašla sam u izvornom pedagogijskom 
pojmu - pedagoškom odnosu - kroz koji pomičem fokus s onoga što se podučava na ono kako se podučava, naglašavajući odnosnu vezu učenika i učitelja. Smatram kako je artikulacija pedagoškog odnosa unutar baletne nastave ključni faktor njezina kvalitativnog unapređenja te kako jedino kroz tu artikulaciju ples/balet može umjesto cilja postati sredstvo odgoja djeteta u svestraniju i bogatiju ličnost. ${ }^{18}$

Uz sve navedeno, smatram kako redizajn baletnoj umjetnosti može donijeti jedino obrazovanje, i to kroz stvaranje kritične mase akademski obrazovanih plesnih praktičara koji će biti svjesni važnosti pedagoškog pristupa, ali i potrebe njegova stalnog kritičkog preispitivanja i nadogradnje. Čini mi se, naime, kako upravo zbog nedostatka "kritičke intervencije" propuštamo, udivljeni fantastičnom disciplinom i radnom etikom mladih plesača, promotriti sadržaj skrivenog kurikuluma, tj. svega onoga što je, podržano tradicijom i pod izlikom "specifičnosti profesije", implicitno sadržano u procesu baletnog školovanja. Jedino će se tako mlade osobe izašle iz tog sustava moći nositi sa svim izazovima koje baletna profesija pred njih postavlja te, po mogućnosti, i same mijenjati status quo.

Christopher Hampson, ravnatelj škotskog baleta, kaže: “želim nešto više od lijepog tijela i dobre tehnike. Zainteresiran sam za onoga tko može nešto donijeti kao umjetnik i time obogatiti repertoar - pokoran i popustljiv plesač to neće napraviti" (Hampson u Mackrell 2018: 4). Upravo je zato važno raditi i na osvještavanju šire zajednice te stvaranju nove generacije profesionalaca koji su sposobni pokrenuti promjenu unutar vlastite profesije te zastarjeli devetnaestostoljetni balet pretvoriti u uzbudljivu i potentnu umjetnost današnjice, oslobođenu diskriminatornih praksi koje ju opterećuju i obilježavaju.

\section{LITERATURA I IZVORI}

Alten, Anna. 2002. “Izvedbenost tijela, stvaranje kulture”. Kretanja 1: 46-56.

Barthes, Roland. 2009. Mitologije. Zagreb: Pelago.

Bašić, Slavica. 1999. “Odgoj”. U Osnove suvremene pedagogije. Antun Mijatović, ur. Zagreb: Hrvatski pedagoško književni zbor, 175-203.

Bašić, Slavica. 2009. “Dijete (učenik) kao partner u odgoju. Kritičko razmatranje”. Odgojne znanosti 11/2: $27-44$

Bašić, Slavica. 2015. "Svrha i obilježja pedagoškog odnosa”. U Odgoj u školi. Siniša Opić, Vesna Bilić i Marko Jurčić, ur. Zagreb: Učiteljski fakultet Sveučilišta u Zagrebu, 11-43.

Bazarova, Nadežda i Varvara Mei. 1973. Alphabet of Classical Dance. Beograd: Udruženje muzičkih pedagoga Srbije.

${ }^{18}$ Ova je rečenica parafraza jedne od osnovnih premisa funkcionalne muzičke pedagogije koja predstavlja izvrstan primjer neautoritarne umjetničke pedagogije. Tako, prema riječima glazbene pedagoginje Elly Bašić, "svako dijete, a ne neko dijete ima pravo na muzičku kulturu" (Bašić u Letica 2014). Upravo taj inkluzivni pristup škole (Glazbeno učilište Elly Bašić), koja upisuje sve učenike bez audicije, omogućuje ostvarenje punog obrazovnog potencijala djeteta stoga što škola djeluje na više razina te ne obrazuje samo profesionalne kadrove (glazbenike, pjevače) već odgaja i obrazuje i potencijalnu publiku što je, u kontekstu umjetničkog obrazovanja, izuzetno važno. 
Biti, Ozren. 2012. Nadzor nad tijelom. Vrhunski sport iz kulturološke perspektive. Zagreb: Institut za etnologiju i folkloristiku.

Bolt, Jennifer M. 2008. Silencing the Silent: A Feminist Analysis of Classical Ballet within a Canadian University Dance Program. Toronto: York University, 1-20.

Clement, Jennifer. 2007. Reforming Dance Pedegogy. A Feminist Perspective on the Art of Performance and Dance Education. Diplomski rad. University of South Florida.

Gulin Zrnić, Valentina. 2006. "Domaće vlastito i osobno: autokulturna defamilijarizacija". U Etnologija bloskoga. Poetika i politika suvremenih terenskih istraživanja. Jasna Čapo Žmegač, Valentina Gulin Zrnić i Goran Pavel Šantek, ur. Zagreb: Institut za etnologiju i folkloristiku, Naklada Jesenski i Turk, 73-95.

Devald Roksandić, Mihaela. 2016. O objektivizaciji balerine. Promišljanja feminističke kritike baleta. Zagreb: Akademija dramske umjetnosti.

Freire, Paolo. 2002. Pedagogija obespravljenih. Zagreb: Odraz.

Fromm, Erich. 1984. Autoritet i porodica. Zagreb: Naprijed.

Glazbeno učilište Elly Bašić. Dostupno na: http://www.ellybasic.hr/?page_id=22 (pristup 15. 12. 2017.).

Howse, Justin. 2000. Dance Technique and Injury Prevention. London: A\&C Black Publishers Limited.

Juul, Jesper i Helle Jensen. 2010. Od poslušnosti do odgovornosti. Zagreb: Naklada Pelago.

Katarinčić, Ivana. 2013a. "Baletno tijelo kao prostor fascinacije i diskriminacije". Narodna umjetnost 50/2: 68-86. https://doi.org/10.15176/VOL50NO204

Katarinčić, Ivana. 2013b. "Rod u predodžbama. Stereotipizacija u klasičnom baletu”. Studia ethnologica Croatica 25/1: 283-304.

Konvencija o pravima djeteta. Dostupno na: http://www.unicef.hr/wp-content/uploads/2017/05/Konvencija_20o_20pravima_20djeteta_full.pdf (pristup 1. 12. 2017.).

Lawrence, Wanessa. 2012. "Caviar with Russian Ballerina Natalia Makarova”. Dostupno na: https://www. wmagazine.com/story/natalia-makarova-russian-ballerina-documentary (pristup 9. 11. 2018.).

Letica, Marina, ur. 2014. Vjerujem svakom djetetu. Zagreb: Glazbeno učilište Elly Bašić.

Mackrell, Judith. 2018. "Death of the Dance Dictators. Ballet in the Wake of \#Me Too". The Guardian. Dostupno na: https://www.theguardian.com/stage/2018/jul/16/dance-ballet-metoo-culture-bullying (pristup 31. 5. 2019.).

Midtgaard, Magdalena I. 2016. Ballet, Culture and Elite in the Soviet Union. Umeå: Umeå Universittet.

Mosston, Muska i Sara Ashworth. 2008. Teaching Physical Education. Boston: Benjamin Cummings.

Neuweg, Georg Hans. 2008. Šutnja znalaca. Zagreb: Erudita.

Pavičić Vukičević, Jelena. 2013. “Uloga implicitne teorije nastavnika u skrivenom kurikulumu suvremene škole". Pedagogijska istraživanja 10/1: 119-133.

Pickard, Angela. 2015. Ballet Body Narratives. Pain, Pleasure and Perfection in Embodied Identity. Bern: Peter Lang. https://doi.org/10.3726/978-3-0353-0717-7

Risner, Doug. 2000. "Making Dance, Making Sense. Epistemiology and Choreography". Research in Dance Education 1/2: 155-172. https://doi.org/10.1080/713694259

Sadono, Regina Fletcher. 1998. Details and Reproducing Domination. The Birth of the Ballet School, the Prison, and Other Correctional Facilities. University of California. Dostupno na: https://escholarship. org/content/qt77j808qq/qt77j808qq.pdf (pristup 2. 5. 2019.).

Shapiro, Sherry B. 1999. Pedagogy and the Politics of the Body. New York: Garland Publishing, INC.

Širanović, Ana. 2016. Poštovanje prava djeteta kao pokazatelj kvalitete odnosa učenika i učitelja. Doktorska disertacija. Zagreb: Filozofski fakultet Sveučilišta u Zagrebu. 
Širanović, Ana. 2017. "Modeli dječje participacije u funkciji pedagoške elaboracije sudjelovanja djece".

U Pravo djeteta na odgoj i obrazovanje. Teorije, politike i prakse. Dubravka Maleš, Ana Širanović i Adrijana Višnjić Jevtić, ur. Zagreb: Filozofski fakultet Sveučilišta u Zagrebu, 136-151.

Škola za klasični balet. Dostupno na: http://www.skolazaklasicnibalet.hr/odjel-za-klasicni-balet/ (pristup 1. 12. 2017.).

Wainwright, Steven, Williams Clare i Turner Bryan S. 2006. "Varieties of Habitus and the Embodiment of Ballet". Qualitative Research, 535-558. https://doi.org/10.1177/1468794106068023

Yamashita, Cayley. 2013. The Shift in Pedagogy. Authoritarian and Egalitarian Styles of Teaching. Loyola Marymount University and Loyola Law School.

\section{THE PEDAGOGICAL RELATIONSHIP AS CONTEXT CHANGE POTENTIAL IN BALLET EDUCATION}

This paper explores ballet education from a pedagogical perspective, viewing it primarily as an educational process. In this sense, oppressive pedagogical practices are analyzed, defined as attitudes and values that are traditionally transmitted from one generation to the next within the ballet educational hierarchy without critical questioning. The paper focuses on the Rights of the Child and their human rights in the educational process, analyzing the discriminatory patterns of child selection that continue to exist in ballet schools around the world even today. Thus, the focus shifts from what is "important to the profession" to regarding the best interests and welfare of the child in the ballet educational process. The approach is qualitative, and based on autoethnography, where various personal experiences are included, experiences gained through education, dancing and teaching. Based on these experiences and theoretical research, the paper attempts to offer a change in the process of ballet education and finds it precisely in its pedagogical contribution to ballet pedagogy. The needed change is the shift in the quality of the teacher-student relationship, and it is presented as a pedagogical relationship because it is the awareness and articulation of all segments of the pedagogical relationship that bring about the potential change that is necessary for the ballet education process. The articulation of the pedagogical relationship as a basic pedagogical concept still respects the demands of ballet art, but at the same time does not neglect the child's position within ballet education as well as the child's best interest in it.

Keywords: ballet education, ideal ballet body, discrimination, authoritarian pedagogical practices, pedagogical relationship 